\title{
Kontribusi Izin Pemungutan dan Pemanfaatan Kayu (IPPK) 100 ha terhadap Pendapatan Daerah: Studi Kasus di Kabupaten Bulungan
}

Oleh Samsu, Heru Komarudin, Sian McGrath, Yan Ngau dan Dt. Iman Suramenggala

\section{IPPK: Kebijakan Berorientasi Ekonomi?}

Setelah jatuhnya rezim Soeharto, pemerintah Indonesia memberlakukan sistem desentralisasi dengan melimpahkan sebagian wewenang pengelolaan sumberdaya alam ke tingkat kabupaten dan provinsi, serta memperbesar dana perimbangan dari sektor kehutanan. Berdasarkan peraturan perundang-undangan, Bupati diberikan wewenang untuk mengeluarkan izin pengusahaan hutan skala kecil dengan luasan di bawah 100 ha. Kebijakan ini hanya terbatas pada kawasan hutan yang belum dibebani hak atau di kawasan hutan produksi yang dapat dikonversi ${ }^{1}$. Sekalipun ada keterbatasan, hampir semua kabupaten di Indonesia yang memiliki hutan memanfaatkan kewenangan tersebut. Namun demikian, dalam perkembangannya, peraturan perundangan kehutanan yang memberikan wewenang kepada Bupati tersebut kemudian dibatalkan oleh Menteri Kehutanan dan pada tahun 2003 hampir semua kabupaten telah menghentikan penerbitan izin-izin pemanfaatan kayu skala-kecil.

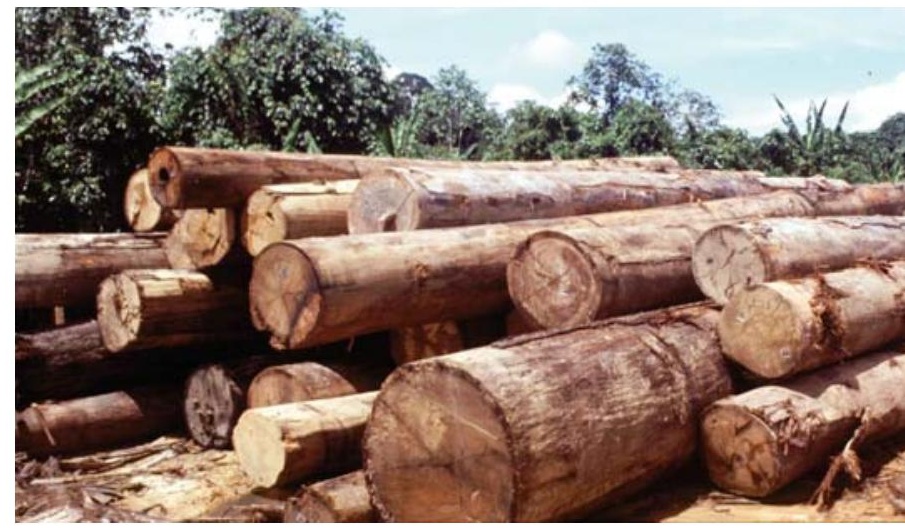

Kayu tebangan di Kabupaten Bulungan, Kalimantan Timur. (Foto oleh Yani Saloh)

Tujuan nasional kebijakan desentralisasi di sektor kehutanan adalah untuk membantu memperkuat perekonomian daerah dan meningkatkan efisiensi, efektivitas, dan akuntabilitas pengelolaan hutan. Undang-undang tentang Perimbangan Keuangan Antara Pemerintah Pusat dan Daerah ${ }^{2}$ menyatakan bahwa penerimaan daerah bersumber dari Pendapatan Asli Daerah (PAD), Dana Perimbangan, Pinjaman Daerah dan "Lain-lain penerimaan yang sah"3.

Sesuai dengan peraturan perundangan, pemerintah daerah mengeluarkan peraturan daerah guna mengatur ijin pengusahaan kayu. Kepala daerah dapat pula mengeluarkan produk hukum berupa keputusan-keputusan yang pemberlakuannya tidak melalui persetujuan Dewan Perwakilan Rakyat Daerah (DPRD).

Dengan keluarnya SK Menteri Kehutanan pada tahun 1999 yang memberikan kewenangan kepada kepala daerah untuk mengeluarkan ijin pengusahaan kayu skala kecil ${ }^{4}$, Bupati Bulungan menanggapinya dengan mengeluarkan sebuah keputusan pada tanggal 28 Juni 2000 yang mengatur tentang pemberian izin pemungutan hasil hutan kayu pada hutan milik, hutan rakyat dan hutan adat. ${ }^{5}$

Peraturan Daerah (Perda) Bulungan No. 17 tentang Retribusi Izin Pemungutan dan Pemanfaatan Kayu pada Hutan Milik/Hutan Rakyat menyusul diterbitkan pada tanggal 2 November $2000^{6}$. Perda ini menetapkan kebijakan kabupaten dalam rangka pembinaan, pengawasan dan pemanfaatan sumberdaya alam, khususnya hutan rakyat dan hutan milik serta mengatur pungutan retribusi atas izin pemungutan dan pemanfaatan kayu, atau yang lebih dikenal dengan istilah setempat IPPK 100 ha. 
Selain untuk meningkatkan peluang masyarakat mendapat manfaat dari sumberdaya hutan, kebijakan-kebijakan tersebut juga dimaksudkan untuk meningkatkan Pendapatan Asli Daerah (PAD). Surat keputusan Bupati memuat pengaturan tentang lokasi izin, tata cara permohonan izin, prosedur tata usaha kayu, kewajiban pemegang izin untuk melakukan penanaman kembali bekas areal dan mengelola dampak-dampak sosial. Sementara itu, aturan yang lebih tinggi, yaitu peraturan daerah, mengatur penarikan retribusi. Hal ini menunjukkan bahwa pertimbangan aspek ekonomi lebih diutamakan dimana peraturan yang mengatur penarikan dan pembayaran retribusi terlebih dahulu disetujui oleh DPRD. Artinya, masyarakat melalui wakil-wakilnya di DPRD hanya mempunyai kesempatan memberikan masukan untuk halhal yang menyangkut ekonomi dan bukan dalam masalah-masalah sosial dan lingkungan.

Dalam waktu yang singkat, pemerintah kabupaten juga berhasil meningkatkan PADnya dari pengenaan retribusi izin ekspor atas kayu bulat yang berasal dari hutan milik dan hutan rakyat. Dua peraturan daerah yang secara khusus mengatur hal tersebut dikeluarkan secara berturut-turut oleh bupati pada tahun 20017, namun demikian masa berlakunya hanya efektif selama 7 bulan setelah dicabut menyusul terbitnya Surat Keputusan Bersama (SKB) Menteri Kehutanan dan Menteri Perindustrian dan Perdagangan. SKB tersebut melarang ekspor kayu bulat/kayu serpih ${ }^{8}$.

Sebagian besar masyarakat setempat menyambut baik keluarnya kebijakan IPPK. Mengingat terbatasnya modal dan kapasitas, masyarakat setempat mencari investor atau pengusaha HPH untuk bermitra mengusahakan kayu di atas areal hutan milik dan hutan adat. Atas nama masyarakat, pengusaha atau investor mengajukan permohonan izin kepada bupati untuk mengusahakan areal hutan yang telah disepakati terlebih dahulu dengan masyarakat setempat. Tingginya minat masyarakat untuk memperoleh IPPK didorong oleh beberapa alasan seperti proses pengajuan izin yang sederhana, cepat dan mudah; modal yang tidak terlalu besar untuk mendapatkan keuntungan finansial dan untuk memasok kayu legal dalam waktu yang singkat serta terbukanya secara luas pasar kayu bulat menyusul keluarnya kebijakan tersebut.

Jumlah izin yang diterbitkan di Kabupaten Bulungan melonjak dari yang hanya 40 buah pada tahun 1999, menjadi 585 izin pada tahun 2000. Pada tahun 2001, tidak ada izin baru yang dikeluarkan, namun tercatat masih sekitar 618 IPPK melakukan kegiatannya. Walaupun beberapa izin perpanjangan masih tetap dikeluarkan dalam kurun waktu tahun 2002-2003, jumlah izin yang beroperasi sudah sangat sedikit karena setidaknya dua alasan. Pertama, pemerintah pusat telah mulai menarik kembali kewenangan bupati dan mengambil langkah-langkah untuk menghentikan pemberian izin. Kedua, luas hutan di luar kawasan hutan yang menjadi lokasi dikeluarkannya IPPK terus berkurang dengan sangat cepat. Akhirnya, pada bulan Februari 2004 Bupati menghentikan pemberian izin melalui sebuah surat keputusan yang salah satu isinya berbunyi bahwa Pemerintah Kabupaten Bulungan tidak lagi menerbitkan izin, baik yang baru maupun perpanjangan/revisi, sampai dengan adanya penugasan yang jelas dari Pemerintah Pusat. Berdasarkan penelitian, terungkap bahwa penghentian tersebut juga karena adanya keprihatinan pemerintah daerah atas kurangnya manfaat yang dirasakan langsung oleh masyarakat lokal yang sumberdaya hutannya dieksploitasi.

Yayasan Pionir dan CIFOR menganalisis ketentuanketentuan terkait pemungutan retribusi dan pengelolaan administrasinya yang dilakukan pemerintah Kabupaten Bulungan. Kajian juga dilakukan terhadap jumlah izin yang dikeluarkan dan jumlah kayu yang dipanen dari areal IPPK 100 ha, dan angkanya dibandingkan dengan penerimaan pendapatan kabupaten dari sektor kehutanan dan pengeluaran yang tercermin dalam Anggaran Pendapatan dan Belanja Daerah. Kajian tersebut menghasilkan rekomendasi yang cukup penting dalam upaya memperbaiki akuntabilitas dan transparansi dalam pengelolaan retribusi dari sektor kehutanan di tingkat nasional dan kabupaten.

\section{Berapa besar kontribusi kebijakan IPPK 100 ha bagi pendapatan}

\section{kabupaten?}

Kontribusi dari kebijakan IPPK terhadap pendapatan kabupaten terwujud di dalam beberapa komponen, yakni sumbangan pihak ketiga, retribusi izin ekspor kayu bulat dan retribusi kayu bulat serta dana perimbangan yang disetor kepada pemerintah pusat dan didistribusikan kembali melalui mekanisme perimbangan keuangan:

\section{Pendapatan Daerah}

1. Sumbangan pihak ketiga. Peraturan Daerah No. $17 / 2000$ tidak mengatur sumbangan ini, namun pengaturan penerimaan sumbangan tersebut merujuk pada Peraturan Daerah sebelumnya (juga bernomor 17) yang dikeluarkan tahun $1998^{9}$ yang mengatur suatu mekanisme bagi penarikan "sumbangan pihak ketiga" dari berbagai kegiatan usaha, termasuk izin usaha pengusahaan hutan. Sumbangan untuk kegiatan IPPK ditetapkan sebesar Rp. 200.000/ha dan dibayarkan satu kali ketika izin dikeluarkan. Sumbangan pihak ketiga adalah sumbangan sukarela. Penelitian kami menunjukkan bahwa perusahaan-perusahaan pemegang IPPK tidak selalu membayar sumbangan tersebut. Pada 
Tabel 1. Pendapatan daerah dari sumbangan pihak ketiga dan retribusi kayu bulat

\begin{tabular}{|rrrrrrrr}
\hline No & Tahun $\begin{array}{r}\text { Jumlah izin } \\
\text { yang beroperasi } \\
\text { (Kumulatif) }\end{array}$ & $\begin{array}{r}\text { Luas } \\
(\mathbf{h a})\end{array}$ & $\begin{array}{r}\text { Produksi } \\
\left(\mathrm{m}^{3}\right)\end{array}$ & $\begin{array}{r}\text { Realisasi Penerimaan (Rp } \\
\text { 000) }\end{array}$ & $\begin{array}{r}\text { Sumbangan } \\
\text { pihak ketiga }\end{array}$ & $\begin{array}{r}\text { Retribusi } \\
\text { kayu bulat }\end{array}$ & Jumlah total \\
(Rp 000)
\end{tabular}

Sumber: Kantor Dinas Pendapatan Daerah (Dispenda) Kab. Bulungan (data realisasi).

tahun 2000 dan 2001, tercatat hanya 59 dari 618 pemilik IPPK yang membayar sumbangan tersebut.

2. Retribusi izin ekspor kayu bulat. Walaupun hanya berlaku efektif selama tujuh bulan, retribusi ini memberikan sumbangan yang cukup berarti terhadap PAD (Rp. 7,5 miliar). Tarif ekspor dikenakan berdasarkan jenis dan volume kayu bulat yang diekspor. Sebagai contoh, tarif retribusi untuk jenis kayu meranti adalah Rp. $120.000 / \mathrm{m}^{3}$.

3. Retribusi kayu bulat. Retribusi ini adalah royalti atas setiap meter kubik kayu yang diambil dengan tarif tergantung pada jenis kayu, antara lain Rp. $25.000 / \mathrm{m}^{3}$ untuk jenis rimba campuran, Rp. $60.000 / \mathrm{m}^{3}$ untuk kelompok meranti, dan Rp. $75.000 / \mathrm{m}^{3}$ untuk kayu indah.

\section{Dana Perimbangan}

4. Provisi Sumber Daya Hutan (PSDH) dan Dana Reboisasi (DR). PSDH dan DR disetorkan pemegang izin kepada pemerintah pusat. Pemerintah pusat menerima bagian 20\% dari PSDH, dan mendistribusikan sisanya kembali ke kabupaten dan provinsi. Provinsi menerima $16 \%$, Kabupaten Bulungan menerima $32 \%$, dan sisa $32 \%$ dari PSDH $^{10}$ didistribusikan kepada kabupaten-kabupaten lain di Kalimantan Timur. Dari penerimaan Dana Reboisasi (DR), pemerintah pusat mengembalikan $40 \%$ bagian kepada Provinsi Kalimantan Timur, yang kemudian akan mendistribusikan sebagian dari dana tersebut kepada Kab. Bulungan. Sisa bagian 60\% didistribusikan kepada kabupatenkabupaten lain, baik daerah penghasil maupun tidak.

Total kontribusi kebijakan IPPK (dari sumber daerah dan dana perimbangan) hanya $2,5 \%$ dari total pendapatan daerah tahun 2000 (Rp. 95,5 miliar). Pada tahun 2001, ketika kabupaten mengenakan tarif atas ekspor kayu bulat selama tujuh bulan, kontribusinya meningkat menjadi 3,9\% dari total anggaran (Rp. 413 miliar). Proporsi sumbangan IPPK terhadap anggaran daerah menurun tajam menjadi 0,26\% dari total anggaran tahun 2002 (Rp. 587 miliar).

Kebijakan IPPK telah memberikan kontribusi yang cukup signifikan terhadap PAD Kabupaten Bulungan. Pada tahun 1999 besarnya PAD kurang dari Rp. 2 miliar. Pada tahun 2000, IPPK menyumbang lebih dari Rp. 2,3 miliar atau hampir 50\% dari PAD Kabupaten Bulungan yang mencapai Rp. 4,7 miliar. Penerimaan dari retribusi sumbangan pihak ketiga dan retribusi kayu bulat meningkat tajam pada tahun 2001 menjadi Rp. 8,7 miliar, atau 39,7\% dari total PAD yang mencapai 21,9 miliar. Peningkatan penerimaan PAD dalam periode tersebut juga disebabkan oleh adanya pungutan retribusi ekspor kayu bulat. Jika ditambah dengan penerimaan dari retribusi ekspor kayu bulat ${ }^{11}$ yang nilainya mencapai Rp. 7,6 miliar, maka total kontribusi IPPK terhadap PAD mencapai $74 \%$.

Tabel 2. Kontribusi IPPK terhadap DR dan PSDH yang disetor ke pemerintah pusat dan penerimaan daerah melalui DAK-DR, untuk tujuh dari 13 kecamatan di Kabupaten Bulungan

\begin{tabular}{|c|c|c|c|c|c|c|}
\hline \multirow[t]{2}{*}{ Tahun } & \multirow[t]{2}{*}{ Produksi $\left(\mathrm{m}^{3}\right)$} & \multirow{2}{*}{$\begin{array}{r}D^{*} \\
(\text { Rp. 000) }\end{array}$} & \multirow{2}{*}{$\begin{array}{r}\text { PSDH } \\
\text { (Rp. 000) }\end{array}$} & \multirow{2}{*}{$\begin{array}{r}\text { Jumlah total } \\
\text { DR+PSDH } \\
\text { (Rp. 000) }\end{array}$} & \multicolumn{2}{|c|}{$\begin{array}{c}\text { Penerimaan Daerah dari Dana } \\
\text { Perimbangan (Rp. 000) }\end{array}$} \\
\hline & & & & & DAK-DR & PSDH \\
\hline 2000 & $129.024,19$ & 1.951 .310 & 1.105 .543 & $3.056 .852,81$ & & \\
\hline 2001 & $538.134,96$ & 15.706 .025 & 7.324 .453 & $23.030 .477,52$ & 17.606 .565 & 3.726 .945 \\
\hline 2002 & $226.612,39$ & 27.300 .175 & 12.623 .724 & $39.923 .898,71$ & 4.904 .112 & 5.488 .349 \\
\hline 2003 & $404.212,22$ & 64.392 .271 & 19.991 .499 & 84.383 .770 & 30.397 .515 & 21.194 .115 \\
\hline
\end{tabular}

Sumber: UPTD Dinas Kehutanan Provinsi (2003). Jumlah total adalah penerimaan dana DR/PSDH yang bersumber dari produksi kayu IPPK di Kab. Bulungan di wilayah UPTD Bulungan. *Asumsi nilai tukar adalah 1US\$ = Rp 8.500. Penerimaan iuran kehutanan dari HPH skala besar yang izinnya dikeluarkan oleh pusat tidak termasuk dalam tabel. 


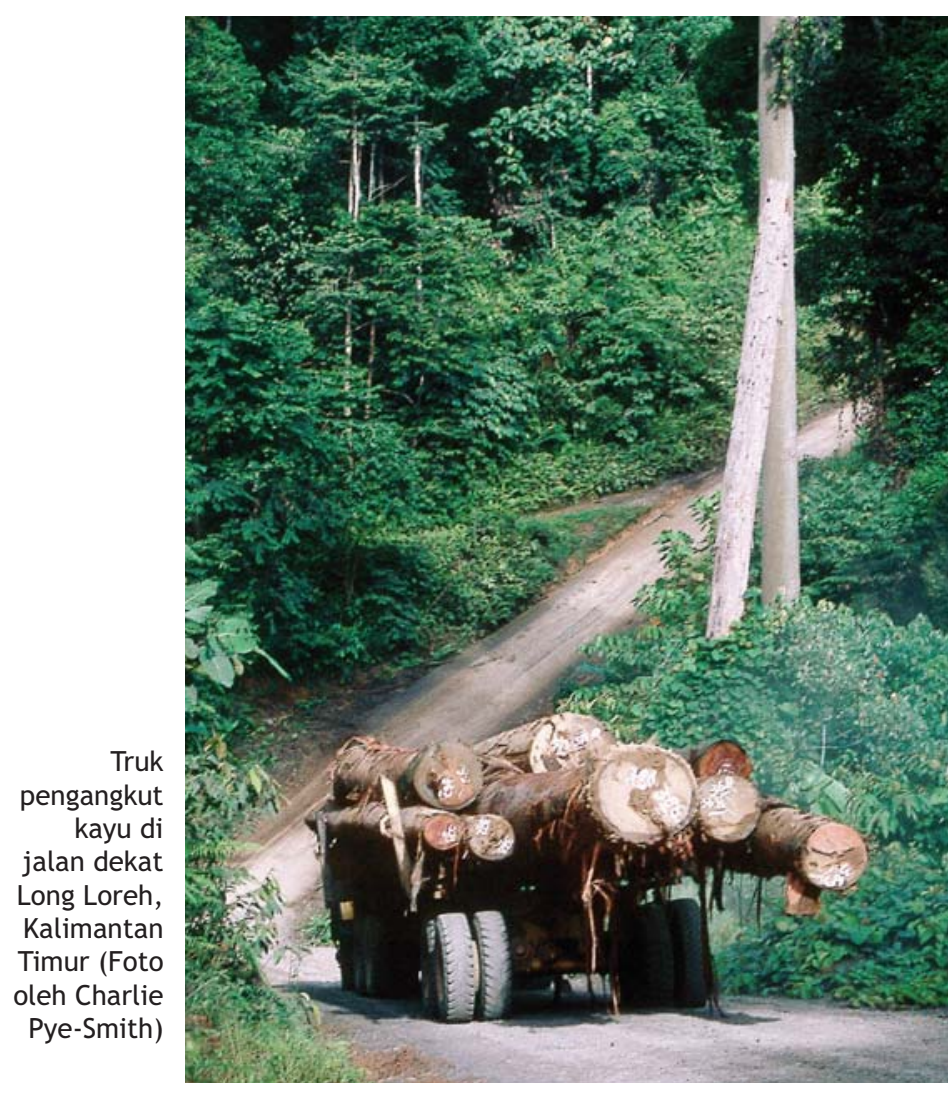

Selain terhadap PAD, IPPK juga mempunyai kontribusi yang tidak sedikit terhadap penerimaan daerah melalui dana perimbangan yang ditransfer pemerintah pusat kepada daerah dari DR dan PSDH. Total penerimaan dari dana perimbangan melalui DAK-DR adalah sebesar Rp 17,6 miliar pada tahun 2001, Rp. 4, 9 miliar tahun 2002, dan Rp. 30,4 miliar tahun 2003.

\section{Fakta di balik angka}

Berdasarkan analisis dan perhitungan lanjutan, kontribusi dari para pemegang IPPK seharusnya lebih besar daripada jumlah penerimaan yang tercatat resmi di Kantor Dispenda (Tabel 1). Perhitungan ini didasarkan atas jumlah izin dan volume kayu yang diproduksi melalui IPPK, jumlah penerimaan dari sumbangan pihak ketiga, dan retribusi kayu bulat.

Sebagai contoh, dari Kabupaten Bulungan (diluar Kecamatan Sesayap, Sesayap Hilir, Bunyu, dan Tanah Lia $^{12}$ ) tercatat jumlah total produksi kayu bulat pada periode tahun 2000-2003 sebesar 1.612.550,85 $\mathrm{m}^{3}$. Dengan jumlah sebesar itu, maka Kabupaten Bulungan seharusnya menerima PAD dari retribusi kayu bulat sebesar antara Rp. 40,3 miliar hingga Rp. 96,7 miliar. Kenyataannya, catatan penerimaan dalam anggaran daerah menunjukkan hanya sebesar Rp. 11 miliar (Tabel 1). Dengan asumsi tarif retribusi untuk golongan jenis meranti adalah Rp. $60.000 / \mathrm{m}^{3}$ dan jenis rimba campuran Rp. $25.000 / \mathrm{m}^{3}$, maka pendapatan yang diterima seharusnya adalah antara Rp. 29,1 miliar hingga Rp. 85,5 miliar. Hal yang sama juga terjadi pada jumlah penerimaan dari sumbangan pihak ketiga dengan jumlah yang tercatat dalam anggaran daerah. Selisih antara yang seharusnya dibayar dengan realisasi mencapai Rp. 3 miliar untuk periode waktu 2000 dan 2003.

Salah satu kemungkinan penyebab besarnya selisih adalah lemahnya koordinasi antara proses pemungutan pajak/retribusi tingkat kabupaten dengan proses pemberian izin pengangkutan kayu. Berdasarkan peraturan perundangan-undangan yang berlaku ${ }^{13}$, pemegang hak hanya dapat memasarkan dan mengangkut kayu bulat setelah mendapatkan Surat Keterangan Sahnya Hasil Hutan (SKSHH) yang diterbitkan pejabat berwenang. Sementara itu, Perda No. 17 tahun 2000 tidak mengatur dengan jelas mengenai mekanisme pemungutan dan pembayaran retribusi. Pasal 9 Perda tersebut menyebutkan bahwa tata cara pemungutan, pembayaran, penagihan retribusi diatur lebih lanjut oleh Keputusan Bupati. Tetapi, tidak ditemukan satu keputusan pun yang mengatur mekanisme dan tata cara penagihan retribusi tersebut.

Proses penarikan retribusi kayu bulat tidak berjalan efektif. Pemerintah provinsi menerbitkan SKSHH kepada pemilik izin begitu mereka telah membayar pajak/retribusi. Hal ini menyebabkan Dispenda kabupaten tidak memiliki mekanisme untuk mendorong para pemegang izin melakukan pembayaran pajak/retribusi daerah. Perda No. $17 / 2000^{14}$ sebenarnya mengatur sanksi-sanksi administratif dan pidana bagi wajib retribusi yang tidak melaksanakan kewajibannya. Dalam Perda tersebut disebutkan bahwa wajib retribusi yang tidak membayar retribusi daerah atas kayu bulat tepat pada waktunya atau kurang membayar dikenakan bunga sebesar $2 \%$ setiap bulan keterlambatan. Bagi mereka yang lalai atas kewajiban membayar retribusi diancam pidana kurungan paling lama 6 bulan atau denda sebanyak-banyaknya empat kali dari jumlah retribusi yang terutang. Dalam prakteknya, sanksi-sanksi tersebut tidak pernah diterapkan.

Ketidakjelasan aturan dan mekanisme penarikan retribusi diduga menjadi salah satu penyebab terjadinya perbedaan jumlah retribusi dari yang seharusnya diterima pemerintah kabupaten dengan realisasi. Tidak adanya upaya penegakan hukum atas pelanggaran ketentuan dan kurangnya koordinasi antar instansi terkait menjadi faktor penyebab utama. Dalam sebuah Lokakarya yang diselenggarakan oleh Yayasan Pionir, CIFOR dan pemerintah daerah pada tanggal 6 Mei 2004, para peserta menyadari adanya kelemahan koordinasi antar instansi pemerintah propinsi dan kabupaten di dalam mengatur dan mengendalikan pemanfaatan hasil hutan. Misalnya di dalam penerbitan SKSHH dan penarikan iuran dari pemegang izin, hubungan kerja, pembagian peranan dan tangung jawab 
yang kurang jelas antar instansi pemerintah telah menyebabkan kurang efektifnya pengendalian hasil hutan kayu dan pemungutan retribusinya dari pemegang izin.

Proses pembuatan peraturan daerah juga merupakan sesuatu hal yang menarik untuk dikaji. Misalnya, Bupati Bulungan mengeluarkan keputusan ${ }^{15}$ tentang pemberian izin pemungutan hasil hutan kayu sebelum DPRD memberikan persetujuan dan menetapkan peraturan daerah tentang retribusi IPPK. Selain itu, walaupun pada tahun 2000 Bupati telah menerbitkan sebuah peraturan ${ }^{16}$ untuk membentuk instansi dinas kehutanan kabupaten, namun peraturan-peraturan pelaksanaan yang diperlukan untuk menjelaskan fungsi, peran, dan tanggung jawab dinas tersebut belum juga diterbitkan sampai Kepala Dinas Kehutanan Kabupaten mengeluarkan surat pada bulan Januari $2003^{17}$. Hal ini menyebabkan ketidakjelasan dan tumpang tindih kewenangan. Sementara itu, izin IPPK terus dikeluarkan dan tidak ada kejelasan hukum mengenai instansi yang diberi wewenang mengatur penarikan retribusi-retribusi hasil hutan, melakukan pemantauan dan pengawasan terhadap pemegang izin dan pelaporan hasil produksi dan sebagainya.

Faktor yang terakhir terkait dengan masih kurangnya kemampuan perangkat daerah di dalam mengelola administrasi keuangan di tingkat kabupaten. Instansi di daerah masih kurang memiliki tenagatenaga yang cukup terampil dan berpengalaman di dalam bidang administrasi keuangan.

Pengelolaan keuangan daerah yang transparan, efisien, dan efektif terutama menyangkut penerimaan iuran di sektor kehutanan menjadi sebuah tantangan yang tidak mudah di era otonomi daerah.

\section{Masa depan}

Setelah pemerintah pusat pada tahun 2000 mencabut kewenangan Bupati untuk mengeluarkan IPPK, terjadi perselisihan yang panjang dan ketidakjelasan wewenang pengelolaan kehutanan. Pemerintah daerah berpendapat bahwa kebijakan IPPK menguntungkan masyarakat lokal dan karena itu merupakan sistem yang jauh lebih baik daripada sistem sebelumnya, yakni sistem Hak Pengusahaan Hutan (HPH). Para pemangku kepentingan setempat juga berpendapat bahwa Undang-undang No. 22/1999 tentang Pemerintahan Daerah memberikan kewenangan yang luas kepada daerah untuk mengelola sumberdaya alam; dan karena kedudukan undang-undang lebih tinggi daripada sebuah keputusan menteri atau peraturan pemerintah, pemerintah daerah tetap mengeluarkan izin tersebut. Pada akhirnya, kebijakan IPPK Bulungan dihentikan secara resmi dengan keluarnya Surat

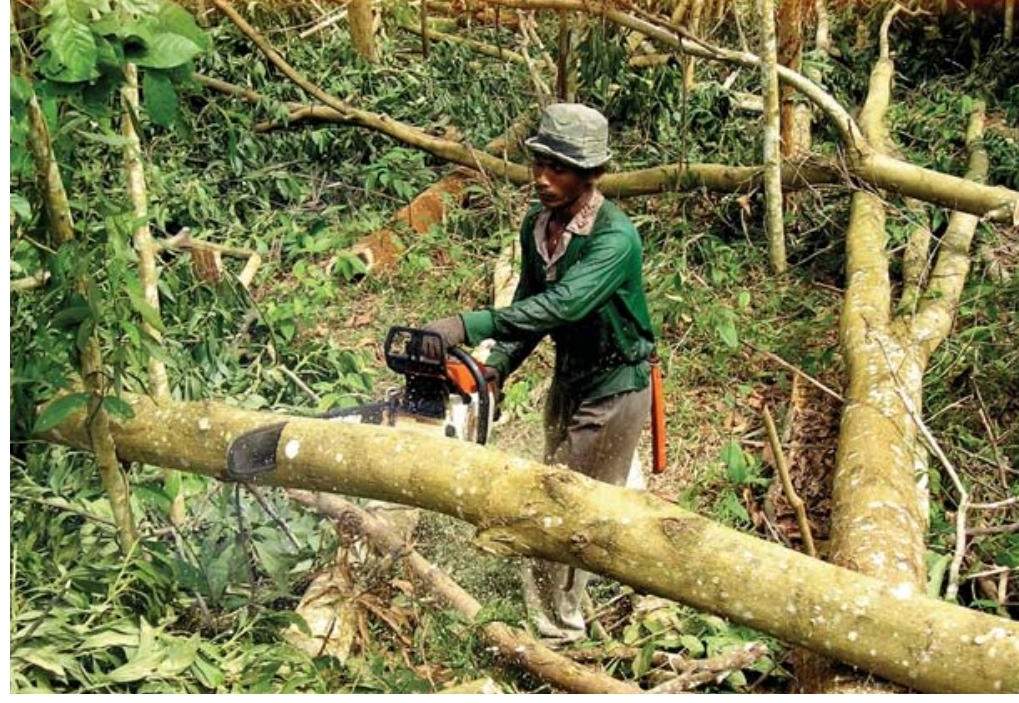

Penebangan kayu oleh masyarakat lokal di Kalimantan Timur (Foto oleh Romain Pirard)

Bupati Bulungan pada tanggal 20 Februari $2004^{18}$, yang menyatakan bahwa pemerintah daerah tidak lagi menerbitkan perijinan baru dan perpanjangan dan masa berlaku seluruh IPPK berakhir pada 31 Desember 2003. Pencabutan kebijakan ini tentu saja akan berpengaruh nyata pada PAD.

Sejalan dengan ditarik kembali kewenangan oleh pemerintah pusat, Pemerintah Kabupaten Bulungan berupaya menggali potensi sumber-sumber keuangan baru untuk membiayai penyelenggaraan pemerintahan dan pembangunan daerah. Pemerintah daerah telah mulai mempertimbangkan pengembangan perkebunan kelapa sawit, yang sebagian besar lokasinya terletak di areal bekas tebangan IPPK ${ }^{19}$. Namun, upaya tersebut tampaknya tidak terlalu memberikan harapan. Dari sembilan izin yang dikeluarkan sejak awal 2004, Bupati mencabut lima karena perusahaan pemegangnya gagal memenuhi persyaratan administrasi dan memulai kegiatan awal seperti land clearing dan penanaman ${ }^{20}$. Selain itu, hasil analisis GIS menunjukkan bahwa 69,7\% dari wilayah kabupaten sebenarnya tidak sesuai untuk perkebunan kelapa sawit, dan dari luas sisanya hanya $21,7 \%$ yang sesuai untuk perkebunan kelapa sawit skala besar.

Berdasarkan wawancara dengan beberapa pimpinan teras pemerintah kabupaten terungkap kemungkinan adanya upaya pemerintah untuk mencari peluang penerimaan PAD dari perusahaan-perusahaan $\mathrm{HPH}$ yang mencakup luasan 784.745 ha - hampir setengah luas wilayah Kabupaten Bulungan. Tetapi yang menjadi pertanyaan sekarang adalah sejauh mana upaya-upaya tersebut sudah memperhitungkan dampak-dampaknya terhadap kelestarian sumber daya alam untuk masa depan, memaksimalkan perolehan pendapatan dan penyediaan lapangan kerja dari lahan hutan di Bulungan? 
Salah satu pelajaran yang paling penting dan relevan adalah bahwa kelemahan-kelemahan di dalam penyusunan dan pelaksanaan kebijakan telah memberi dampak pada kemampuan daerah di dalam memperoleh PAD. Penyebabnya antara lain ketidakjelasan arahan dari pemerintah pusat di dalam pengelolaan keuangan; kontradiksi dan hirarki yang tidak jelas menyangkut kebijakan dan kewenangan antara pemerintah kabupaten dan provinsi; dan mekanisme pengendalian dan pengawasan yang kurang efektif dalam hal pembayaran dan penarikan pajak/retribusi. Walaupun kebijakan tersebut mengatur sanksisanksi administratif dan pidana bagi wajib retribusi yang terlambat melakukan pembayaran retribusi kehutanan, sanksi tersebut tak pernah diterapkan. Kelemahan-kelemahan ini telah menyebabkan sulitnya mewujudkan prinsip-prinsip akuntabilitas dan transparansi, serta terbukanya peluang bagi penyalahgunaan.

Pelajaran lainnya yang bisa dipetik adalah rumusan kebijakan-kebijakan pemerintah pusat, provinsi dan kabupaten harus memuat ketentuan-ketentuan yang lebih jelas dan tegas, dan diwujudkan dalam implementasinya, sehingga akan memberikan manfaat-manfaat sosial ekonomi bagi masyarakat lokal dan menjamin kelestarian sumberdaya hutan dan fungsi lingkungan. Salah satu contoh terkait dengan upaya-upaya perbaikan lingkungan melalui kegiatan reboisasi dan rehabilitasi lahan yang bergantung pada dana DAK-DR dari pusat dengan jumlah mencapai ratusan miliar rupiah. Hasil wawancara penelitian menunjukkan bahwa sebagian pihak memandang peraturan pusat yang mengatur penggunaan dana DAK/DR untuk kegiatan rehabilitasi tidak luwes, dan banyak keluhan muncul terkait dengan keterlambatan pencairan dan jumlah yang tidak sesuai. Hasilnya, kegiatan-kegiatan reboisasi masih belum menunjukkan keberhasilan. Demikian juga, tidak ditemukan ketentuan-ketentuan yang dapat menjadi pedoman bagi pemerintah kabupaten untuk menginvestasikan dana guna meningkatkan keterampilan teknis dan negosiasi yang diperlukan masyarakat sekitar hutan untuk mempertahankan keberlanjutan sumber-sumber daya alam mereka dan meningkatkan kesejahteraan sosial ekonomi mereka ${ }^{21}$.

Dengan demikian, akan sangat bijaksana jika aspek-aspek sosial, ekonomi dan lingkungan selalu dipertimbangkan dengan hati-hati di dalam merumuskan kebijakan-kebijakan terkait dengan pengelolaan keuangan, mengingat besarnya dampak yang ditimbulkan dibandingkan dengan peningkatan penerimaan keuangan semata.

\section{Kesimpulan}

1. Secara ekonomi, kebijakan IPPKberorientasipada peningkatan PAD. Sumbangan kebijakan tersebut terhadap PAD cukup signifikan, tetapi masih sangat kecil proporsinya dibandingkan dengan seluruh anggaran daerah. Anggaran daerah masih sangat bergantung pada penerimaan dari pemerintah pusat, sehingga cukup berpengaruh pada upaya-upaya penciptaan peluang-peluang pembangunan daerah.

2. Kebijakan IPPK seharusnya memberikan sumbangan jauh lebih besar kepada anggaran daerah. Mekanisme penarikan pajak yang tidak jelas dan penerapan sanksi yang lemah telah menyebabkan masih terbatasnya penerimaan daerah dari sektor kehutanan.

\section{Rekomendasi}

1. Sistem pembayaran satu atap untuk semua perizinan di masa depan (produksi kayu dan perkebunan), diharapkan dapat mendorong para pemegang izin untuk melakukan pembayaran tepat waktu; dan mengurangi penyelundupan kayu - jika sistem tersebut dikaitkan dengan proses pemberian izin pengangkutan kayu (SKSHH). Ketika kebijakan IPPK masih aktif berlaku, pemegang izin harus membayar sekurangnya lima jenis pajak yang berbeda, pada waktu yang berbeda pula, dan kepada instansi kehutanan pusat, kabupaten, dan provinsi. Pembayaran satu atap akan mengurangi biaya transaksi dan meningkatkan efisiensi dan transparansi. Hal ini membutuhkan kerja sama diantara instansi terkait, yang koordinasinya mungkin bisa dilakukan oleh Dinas Pendapatan Daerah (Dispenda). Sistem pembayaran yang lebih sederhana juga akan menghindari kebingungan dan memudahkan pemantauan atas akuntabilitas pengelolaan dana-dana tersebut.

2. Partisipasi masyarakat perlu didorong di dalam pembuatan keputusan tentang alokasi penerimaan dana dari sektor kehutanan. Selain itu, pemantauan dan pengawasan sistem juga perlu dilakukan secara terus menerus, sehingga dapat dipastikan bahwa pemerintah daerah menerima uang yang tepat. Hal ini akan membantu terciptanya akuntabilitas dan transparansi di dalam pengelolaan keuangan daerah, dan menampung kepentingankepentingan sosial ekonomi dan lingkungan masyarakat. 


\section{Catatan akhir}

1 SK Menteri Kehutanan No. 05.1/KPTS-II/2000 tentang Kriteria dan Standar Perizinan Usaha Pemanfaatan Hasil hutan dan Perizinan Pemungutan Hasil Hutan pada Hutan Produksi Alam.

2 UU No.25/1999.

3 UU No. 25/1999 Pasal 3.

${ }^{4}$ SK Menteri Kehutanan dan Perkebunan No. 310/KptsII/1999 tentang Pedoman Pemberian Hak Pemungutan Hasil Hutan.

5 SK Bupati No. 196 tahun 2000 tentang Pemberian Izin Pemungutan Hasil Hutan Kayu pada Hutan Milik, Hutan Rakyat dan Hutan Adat.

${ }^{6}$ Menarik untuk dicatat bahwa SK Bupati yang mengatur pemberian izin pemungutan hasil hutan kayu mencakup hutan-hutan milik, hutan rakyat dan hutan adat, sementara peraturan lanjutan yang mengatur retribusi tidak memasukkan hutan adat.

7 Perda No. 1/2001 tentang Izin Ekspor Kayu Bulat dari Hutan Milik / Hutan Rakyat; dan Perda No. 2/2001 tentang Retribusi Izin Ekspor Kayu Bulat dari Hutan Milik/Hutan Rakyat.

8 SK Bersama No. 1132/Kpts-II/2001 dan No. 292/MPP/ Kep/10/2001 tanggal 8 Oktober 2001 tentang Pelarangan Ekspor Kayu Bulat dan Serpihan.

${ }_{9}^{9}$ Perda No. 17/1998 yang diterbitkan pada 31 Oktober 1998 juga disetujui oleh Gubernur Kalimantan Timur dengan SK Gubernur No. 466/1999.
10 UU No. 25/1999 Pasal 6:5.

${ }^{11}$ Dalam waktu yang singkat ketika kebijakan pajak ekspor berlaku (Februari hingga Juni 2001) dari total 62.897,40 $\mathrm{m}^{3}$ kayu yang diekspor dihasilkan devisa sebesar US\$ 7.105.923,41 dan Rp. 12,9 miliar dalam bentuk pajak ekspor. Dinas Pendapatan Daerah melaporkan bahwa mereka menerima Rp. 7,6 miliar dari kayu bulat yang diekspor.

${ }^{12}$ Data tidak tersedia untuk kecamatan-kecamatan Sekatak, Sesayap, Sesayap Hilir, Tanah Lia and Bunyu.

13 SK Menteri Kehutanan No. 126/2003 tentang Penatausahaan Hasil Hutan.

${ }_{14}$ Perda No. 17/2000 Pasal 10-11.

${ }^{15}$ SK Bupati No. 196/2000.

${ }^{16}$ Perda No. 16/2000 tentang Pembentukan Dinas Kehutanan Daerah.

17 Surat Edaran Dinas Kehutanan No. 522.21/67/DISHUT/ II/2003 tanggal 14 Januari 2003.

${ }^{18}$ Surat Bupati Bulungan No. 522/86/Ek.Proda/2004.

19 Lihat "Decentralisation and Forests in Indonesia: Case Study 12, CIFOR, 2005".

${ }^{20}$ Radar Tarakan, 6 Juni 2004.

21 Isu-isu ini dimunculkan oleh para stakeholder dalam rangkaian pertemuan dan lokakarya Kelompok Kerja KKRHL Kabupaten yang diselenggarakan pada tahun 2003 dan 2004. 
Samsu dari Yayasan Pionir Bulungan; Dt. Iman Suramenggala dari Dinas Kehutanan Kabupaten Bulungan; Yan Ngau dari Dewan Perwakilan Rakyat Daerah (DPRD) Kabupaten Bulungan dan Heru Komarudin dan Sian MCGrath dari CIFOR, menyusun Decentralisation Brief ini berdasarkan laporan hasil penelitian tentang "Dampak Desentralisasi Kehutanan terhadap Keuangan Daerah, Masyarakat Setempat dan Tata Ruang - studi kasus di Kabupaten Bulungan, Kalimantan Timur". Kegiatan penelitian ini didanai oleh ACIAR dan DFID melalui proyek penelitian "Can Decentralisation Work for Forests and the Poor?". Pandangan-pandangan yang tertuang dalam tulisan ini adalah dari penulis dan tidak mencerminkan pandangan resmi lembaga pemberi dana.

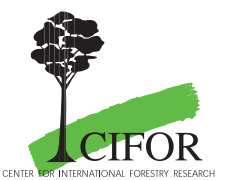

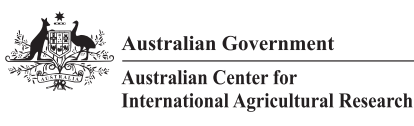

Center for International Forestry Research, CIFOR Office: Jalan CIFOR, Situ Gede, Sindang Barang, Bogo Barat 16680, Indonesia. Mailing: P.O. Box. 6596 JKPWB, Jakarta 10065, Indonesia

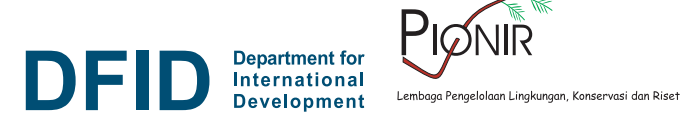

Tel: +62(251) 622622 Fax: +62(251) 622100 E-mail: cifor@cgiar.org Website: www.cifor.cgiar.org

Foto-foto halaman depan oleh Romain Pirard and Christian Cossalter 